\title{
Effects of Information Technology (IT) on Internal Audit in Southwest Nigeria Universities
}

\author{
Gideon Tayo AKINLEYE \& Comfort Temidayo OLANIPEKUN \\ Department of Accounting, Ekiti State University, Ado-Ekiti, Nigeria \\ gtakinleye@eksu.edu.ng,comfort.olanipekun@eksu.edu.ng
}

\begin{abstract}
This study examined the effects of information technology on internal audit in Southwest Nigeria Universities. Primary data were employed and questionnaires were distributed to the selected Universities. Out of 180 questionnaires, 152 questionnaires were filled and returned by the respondents. The study employed factor analysis and binary logit regression analysis as estimation techniques. The findings from factor analysis showed that Kaiser-Meyer-Olkin and Bartlett's tests value was 0.786(78.6\%) implying that the variables have a $78.6 \%$ variation in the data. The value of components variance revealed 62.750 on component 4 indicating that at component 4 there was $62.8 \%$ factor variation in the data. Nonetheless, the logit regression equation revealed that fraud discovery of IT (FD) has a positive and insignificant effect on internal audit. Also, IT effectiveness (ITE) revealed that ITE has a negative and significant effect on internal audit. Equally, asset recovery (AR) exhibited a negative and insignificant effect on internal audit. Furthermore, the external audit (EA) has a positive and insignificant effect on internal audit. This study concluded that a significant relationship exists between information technology and internal audit in Southwest Universities. It was recommended that Universities in Southwest should promote and encourage information technology in the internal audit department and also encourage the external users.
\end{abstract}

Keywords: Information Technology, Audit, Internal Audit, Factor Analysis, Logit.

\section{Introduction}

Information technology has been globally embraced in all sector of the economy where Universities are not left out and its importance cannot be belittled. Technology and economic reforms that occurred in the last decades have significantly affected basic functions and operations of institutions and other business sectors, (Burnaby \& Hass, 2011 as cited by George, Theofanis \& Konstantinos, 2015). The way in which institutions, businesses and other areas have utilized this is by using IT to process their financial information (Al-Fehaid, 2003). Information technology is used by the auditors as a tool to assist in their day to day activities. Solomon and Trotman, (2003) are of the view that the impact of information technology has grown exponentially in recent years and it has changed the audit process which has resulted in opportunities and challenges for auditors. As IT changes occur more quickly, auditors must keep pace with emerging technological changes and their impact on their organisation's data processing system, as well as their own audit procedures (Rezaee and Reinstein, 1998). The introduction of e-payment and e-transact through information technology in the university has encouraged, internal auditors to be familiar with IT procedures. Meanwhile, internal auditors are saddled with the responsibility to safeguarding and to monitoring all the activities in the university, and most of all the activities are computerized using information technology such as students' admission letter, course registration, school fees payment, result checking and some other things. So, information technology has become an integral part of university activities. Nonetheless, the fast changes in the growth of IT require auditors, both internal and external to face a greater challenge in carrying out their duties in the computerized environment.

\section{Literature Review}

In the study of Hermanson, Hill, and Ivancevich, (2000) conducted a study on IT activities of internal auditors in the United States organisations using frequency distribution analysis. Despite the importance of this subject matter, few studies have attempted to examine information technology in relation to internal audit all over the world. The findings showed that IT evaluations, nature of the audit objective, the frequency of computer audit specialists are the factors affecting internal audit performance and presence of new computer information system. Abu-Musa (2008) looked into information technology and its implications for internal auditing among Saudi organizations. Some includes Abu-Rishel and Ivancevich (2003); Musa (2008); Hamdan \& Abzakh (2010); Moorthy, Seetharaman, Mohamed, Gopalan \& San (2011); and Ebiomobowei \& Yadirichukwu (2011); Kombo (2013); Arena (2013); Abiola (2014); Shilla (2014) and Effiok and Bassey 
(2015); Al-Duwaila and AL-Mutairi, (2017). Although, some of these studies were carried out in Nigeria but they were not in the University settings. This necessitates this study to examine the effect of information technology on internal audit in Nigeria Universities most especially in the Southwest public and private universities. The study employed a Kruskal-Wallis test and regression analysis as the estimation techniques. The results revealed that internal auditors must develop their knowledge and skills of information technology for the purpose of reviewing the work done. Also, Hamdan and Abzakh (2010) carried out a study on information technology by the Bahrainis auditors in Dubai. One-sample t-test analysis was employed in the study. The study found that e-audit can improve the evidence obtained by the audit department.

Meanwhile, Mahzan and Veerankutty, (2011) used a correlation matrix to examine the relationship between IT auditing activities of public sector auditors in Malaysia. Their results showed that the most frequent evaluations performed by public sector auditors are application processing control and data integrity, privacy and security control. Ebiomobowei \& Yadirichukwu, (2011) studied the effects of information technology on internal auditors' activities in Nigeria. Multiple regression analysis was used in this study and the findings revealed that information technology usage exhibits the highest relationship with the internal audit. Salehi and Husini, (2011) investigated the effect of information technology on internal audit. T-test binomial test statistical analysis was used. Their findings revealed that information technology enables its users to perform their obligations with a higher validity. Arena (2013) examined the internal audit in Italian universities using chi-square and t-test techniques. The study showed that auditors are shifting from financial and compliance audit to operational audit. Henderson, Davis and Lapke (2013) looked into the effects of internal auditors' information technology knowledge on integrated internal audits in the United States of America.

The study employed partial least square as the estimation technique. The result revealed that IT risks and application controls exhibited a significant effect on integrated internal audits during the study period. More so, Shilla (2014) studied information technology on internal audit in Tanzanian organisations. Information using chi-square test the outcome of the study revealed that the Tanzanian organisations of internal audit departments have not been using IT and auditing IT-based systems effectively. Equally, Effiok and Bassey (2015) examined information technology, audit evidence and financial performance of an organisation in Nigeria from 2007 to 2013. The data were analyzed using multiple regression analysis. The findings of the study revealed that information technology and audit evidence exhibited a positive significant effect on the financial performance of selected companies. Mustapha and Lai, (2017) focused on the usage of information technology for auditors at different levels and positions in audit firms in Malaysia. Descriptive and regression techniques were carried out to analyze the data. The findings showed that information technology is used in the audit practices and it is mainly used by the top management of the organisations.

\section{Methodology}

The population of the study made up of all the 46 Universities in Southwest Nigeria. The University comprises eight state Universities, six federal Universities and thirty-two private Universities in Southwest Nigeria. The sample for this study consists of 180 staff that was selected from the nine (9) universities in Nigeria using a multistage sampling technique. The first stage is the selection of nine (9) universities from Southwest purposively from Ekiti State, Osun State and Ondo State. The second stage is the selection of four (4) subdivisions namely; Payroll and final account, Store and Creditors, Cash and cash advance Management, Revenue and Student Services. The last stage is the random selection of three (3) staff from each of the selected unit a total of respondents. The nine (9) selected Universities in Nigeria, namely Ekiti State, Osun State and Ondo State. The tertiary institutions include: Federal University, Oye (FUOYE), Ekiti State University, Ado-Ekiti (EKSU) and Afe Babalola University, Ado Ekiti (ABUAD), Obafemi Awolowo University (OAU), Osun State University, Joseph Ayo Babalola University (JABU), Adekunle Ajasin University (AAUA), Federal University Technology Akure (FUTA) and Achiever University. The staff made up of the internal audit departments comprises four major divisions in the universities. This study employed Qualitative Response Regression Model of Logit Regression to capture the effect of information technology on internal audit in Nigeria University. Meanwhile, the model is presented as:

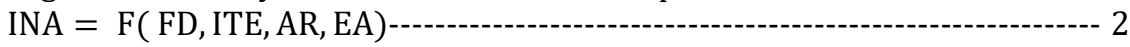

Where

INA $=$ Internal Audit 
FD $\quad=$ Fraud discovery

ITE = Information Technology Effectiveness

AR = Asset Recovery

EA = External Auditor

The econometrics forms of the functional models are specified as:

$\mathrm{INA}=\mathrm{b}_{0}+\mathrm{b}_{1} \mathrm{FD}+\mathrm{b}_{2} \mathrm{ITE}+\mathrm{b}_{3} \mathrm{AR}+\mathrm{b}_{4} \mathrm{EA}+\mu$

Where

INA $=1$ : $p r(I T$ impact on Internal Audit $)$ and $0:$ if otherwise

$\mathrm{b}_{0}$ represents the intercepts or constants;

$b_{1}-b_{4}$ indicates the shift parameters or the coefficients

\section{Results and Discussion}

\section{Results of the Factor Analysis}

Table 1: KMO and Bartlett's Test

\begin{tabular}{lll}
\hline Kaiser-Meyer-Olkin Measure of Sampling Adequacy. & $\mathbf{. 7 8 6}$ \\
\hline \multirow{3}{*}{ Bartlett's Test of Sphericity } & Approx. Chi-Square & 453.096 \\
& DF & 66 \\
& Sig. & .000 \\
\hline
\end{tabular}

Source: SPSS 20.0

The KMO and bartlett's test shows that measure of sampling adequacy values are $0.786(78.6 \%)$ that is the variables such as fraud discovery, it effectiveness, asset recovery and external auditor have 78.6\% variation in the data.

Table 2: Total Variance Explained

\begin{tabular}{|c|c|c|c|c|c|c|c|c|c|}
\hline \multirow{2}{*}{\multicolumn{4}{|c|}{ Component Initial Eigenvalues }} & \multicolumn{6}{|c|}{ Extraction Sums of SquaredRotation Sums of Squared } \\
\hline & & & & \multicolumn{2}{|c|}{ Loadings } & \multirow{2}{*}{\multicolumn{2}{|c|}{$\begin{array}{c}\text { Loading } \\
\text { ofCumulativeTotal }\end{array}$}} & igs & \\
\hline & \multirow[t]{2}{*}{ Total } & $\%$ & \multirow{2}{*}{$\begin{array}{l}\text { ofCumulativ } \\
e \%\end{array}$} & eTotal & $\%$ & & & \multirow{2}{*}{\multicolumn{2}{|c|}{$\begin{array}{l}\text { ofCumulative } \\
\text { ariance } \% \\
\end{array}$}} \\
\hline & & Variance & & & Variance & $\%$ & & & \\
\hline$\overline{1}$ & 3.915 & 32.622 & 32.622 & 3.915 & 32.622 & 32.622 & 2.144 & 17.866 & 17.866 \\
\hline 2 & 1.453 & 12.108 & 44.730 & 1.453 & 12.108 & 44.730 & 2.042 & 17.013 & 34.879 \\
\hline 3 & 1.162 & 9.683 & 54.413 & 1.162 & 9.683 & 54.413 & 1.941 & 16.172 & 51.051 \\
\hline 4 & 1.000 & 8.337 & 62.750 & 1.000 & 8.337 & 62.750 & 1.404 & 11.699 & 62.750 \\
\hline 5 & .842 & 7.019 & 69.769 & & & & & & \\
\hline 6 & .702 & 5.849 & 75.617 & & & & & & \\
\hline 7 & .641 & 5.343 & 80.961 & & & & & & \\
\hline 8 & .585 & 4.876 & 85.837 & & & & & & \\
\hline 9 & .515 & 4.292 & 90.129 & & & & & & \\
\hline 10 & .476 & 3.963 & 94.092 & & & & & & \\
\hline 11 & .408 & 3.400 & 97.492 & & & & & & \\
\hline 12 & .301 & 2.508 & 100.000 & & & & & & \\
\hline
\end{tabular}

Extraction Method: Principal Component Analysis.

Source: SPSS 20.0

This table above indicates the components variance and the result reveals that the eigenvalues and extraction sums of squared loadings have the cumulative percentage of 62.750 on component 4 . This implies that at component 4 there is $62.8 \%$ factor variation in the data.

Table 3: Reliability

\begin{tabular}{ll}
\hline Cronbach's Alpha & N of Items \\
\hline .804 & 12 \\
\hline
\end{tabular}

Source: SPSS 20.0 
The reliability test presented above using Cronbach's Alpha showed that the questionnaires with 12 items were reliable with 0.804 indicating $80.4 \%$ which was above $70 \%$ proposed by Cronbach's Alpha. This implies that the questionnaires were reliable to achieve the broad objective.

\section{Binary Logit Regression Result}

Table 4: Model Summary

\begin{tabular}{llll}
\hline Step & $\mathbf{- 2 ~ L o g ~ l i k e l i h o o d}$ & Cox \& Snell R Square & Nagelkerke R Square \\
\hline 1 & $110.169^{\mathrm{a}}$ & .497 & .573 \\
\hline
\end{tabular}

\section{Source: SPSS 20.0}

The above table reveals the model summary of Cox and Snell R square and Nagelkerke R square. The result shows that Cox \& Snell R square value is 0.497 (49.7\%) implying that the variables have $49.7 \%$ variation to explain the dependent variable while Nagelkerke R square is $0.573(57.3 \%)$ indicating that the control variables can explain $57.3 \%$ variation in the dependent variable.

Table 5: Variables in the Equation

\begin{tabular}{|c|c|c|c|c|c|c|c|}
\hline & & B & S.E. & Wald & DF & Sig. & Exp(B) \\
\hline & FD & .089 & .298 & .088 & 1 & .766 & 1.093 \\
\hline & ITE & -1.400 & .441 & 10.083 & 1 & .001 & .247 \\
\hline \multirow[t]{3}{*}{ Step $1^{\mathrm{a}}$} & AR & -.031 & .325 & .009 & 1 & .924 & .969 \\
\hline & EA & .428 & .323 & 1.755 & 1 & .185 & 1.534 \\
\hline & Constant & 3.456 & .925 & 13.972 & 1 & .000 & 31.700 \\
\hline
\end{tabular}

Source: SPSS 20.0

The variables in the logit equation reveal that fraud discovery of IT (FD) has the coefficient value of 0.089 with a significant value of 0.766 . This implies that FD has a positive and insignificant effect on internal audit. That is, a unit increase in FD will lead to 0.089 increases in internal audit performance. This also means that internal audit has not been using IT as a means of fraud discovery in the University. Also, the coefficient value of IT effectiveness (ITE) is -1.400 with a significant value of 0.001 . This indicates that ITE has a negative and significant effect on internal audit. This implies that IT has made internal audit functions effective. Equally, the coefficient value of asset recovery (AR) is -0.031 and its significant value is 0.924 which implies that AR shows a negative and insignificant effect on internal audit. This shows that IT has not been recovering asset in the Universities in Southwest. More so, the coefficient value of external audit (EA) is 0.428 with a significant value of 0.185 indicating that EA has a positive and insignificant effect on internal audit. This means that external audit use of IT has not been significant on internal audit. Lastly, the coefficient value of constant is 3.456 with significant value 0.000 , implying that, at constant there is a positive and significant effect of IT to internal audit. The findings of this study are similar to the result of Henderson et al. (2013) and Shilla, (2014) that IT applications have a significant impact on internal audits.

\section{Conclusion and Recommendations}

The study concluded that a significant relationship exists between information technology and internal audit in Southwest Universities. It was further concluded that the fraud discovery of IT has a positive and insignificant effect on internal audit implying that internal audit has not been using IT as a means of fraud discovery in the University. Also, IT effectiveness has a negative and significant effect on internal audit meaning that IT has made internal audit functions effective. Equally, asset recovery (AR) exhibited a negative and insignificant effect on internal audit indicating that IT has not been recovering asset in the Universities in Southwest. Furthermore, external audit (EA) has a positive and insignificant effect on internal audit meaning that external audit use of IT has not been significant on internal audit. The study recommended that Universities in Southwest should promote and encourage information technology in the internal audit department and also encourage external users. It is also recommended that asset recovery and fraud discovery of IT should be encouraged in the internal audit department of the University. 


\section{References}

Abiola, J. O. (2014). The Impact of Information and Communication Technology on Internal Auditors Independence: A PEST Analysis of Nigeria. Journal of Scientific Research \& Reports, 3(13), 1738-1752.

Abu-Rishel, T. D. \& Ivancevich S. H. (2003). Additional Opportunities for Internal Auditors in its Implementations. Internal Auditing, 18(2), 35-39

Abu-Musa, A. A. (2008). Information technology and its implications for internal auditing: An empirical study of Saudi organisations. Managerial Auditing Journal, 23(5), 438-466.

Al-Duwaila, N. \& AL-Mutairi A. (2017). The Opinion of Auditors towards the Importance and Knowledge of Information Technology in Kuwait. International Journal of Business and Management, 12(3), 18333850.

Al-Fehaid, A. M. (2003). An investigation of the influence of information technology on audit risk: an empirical study in Saudi Arabia Lough Borough University Institutional Repository.

Al-Refaee, K. \& Saim, A. (2013). The effect of using information technology increasing the efficiency of internal auditing systems in Islamic Bank operating in Jordan. Research Journal of Finance and Accounting, 4(9), 2222- 2847.

Arena, M. (2013). Internal audit in Italian universities: An empirical study. Procedia - Social and Behavioral Sciences, 93, 2000-2005.

Burnaby, P. \& Hass, S. (2011). Internal auditing in the Americas, Management Audit Journal, 26(8), 734-756.

Ebimobowei, A. \& Yadirichukwu, E. (2011). Information technology and internal evidence and financial performance of an organisation. European Journal of Accounting, Auditing and Finance Research, 3(7), 64-71.

Effiok, S. O. \& Bassey, B. E. (2015). Information Technology, Audit Evidence and Financial Performance of an Organisation. European Journal of Accounting, Auditing and Finance Research, 3(7), 64-71.

George, D., Theofanis, K. \& Konstantinos, A. (2015). Factors associated with Internal Audit Effectiveness: Evidence from Greece. Journal of Accounting and Taxation, 7 (7), 113-122.

Hamdan, A. \& Abzakh, M. (2010). The (e-auditing) and its Effects on Persuasiveness of Evidence: Evidence from Bahrain, European, Mediterranean and Middle Eastern, Conference on Information Systems.

Henderson, D., Davis, J. \& Lapke, M. (2013). The effect of internal auditors' information technology knowledge on integrated internal audits. International Business Research, 6(4), 147-162.

Hermanson, D., Hill, M. C. \& Ivancevich, D. M. (2000). Information Technology- Related Activities of Internal Auditors. Journal of Information Systems Auditing Managerial Auditing, 13(8), 465-472.

Kombo, B. (2013). The Effects of Computerized Accounting System on Auditing Process: A Case Study of Mtwara District Council (MDC) (Dissertation for Masters).

Mahzan, N. \& Veerankutty, F. (2011). IT auditing activities of public sector auditors in Malaysia. African Journal of Business Management, 5(5), 1551-1563.

Moorthy, M. K., Seetharaman, A., Zulkifflee, M. Z., Gopalan, M. \& San, L. H. (2011). The impact of information technology on Internal Auditing. African Journal of Business Management, 5(9), 3523-3533.

Mustapha, M. \& Lai, S. J. (2017). Information Technology in Audit Processes: An Empirical Evidence from Malaysian Audit Firms. International Review of Management and Marketing, (2), 53-59.

Rezaee, Z. \& Reinstein, A. (1998). The Impact of Emerging Information Technology on Auditing. Managerial Auditing Journal, UK, 13(8), 465 -471.

Salehi, M. \& Husini, R. (2011). A study of the effect of information technology on internal auditing: Some Iranian evidence. African Journal of Business Management, 5(15), 6169-6179.

Shilla, W. C. (2014). The Impact of Information Technology on Internal Auditing in Tanzanian Organizations. published Dissertation, Tanzania, Mzumbe University.

Solomon, I. \& Trotman, K. (2003). Experimental judgment and decision research in auditing, the first 25 years of AOS. Accounting, Organizations and Society, 28, 395-412. 